\title{
Transactional and Relational Approaches to Political Connections and the Cost of Debt
}

\author{
Taufiq Arifin \\ Universitas Sebelas Maret \\ Iftekhar Hasan \\ Fordham University \\ Rezaul Kabir \\ University of Twente
}

\begin{abstract}
This paper examines the economic effects of a firm's approach to developing and maintaining political connections. Specifically, we investigate whether lenders favor transactional connection as opposed to relational connection. By tracing firms in a politically volatile emerging democracy in Indonesia, we find that firms following a transactional political connection strategy experience a relatively lower cost of debt than those with a relational strategy. The effect is more pronounced for firms facing high financial distress. The finding is robust to cost of bank loans and a variety of regression methods. Overall, the evidence suggests that in times of frequently changing political regimes, firms benefit from a transactional relationship with politicians as it enables to update connection with the government in power. Relational connection is valuable for a firm only when the political regime connected with it gains power.
\end{abstract}

August 2020

Keywords: Political connection, Cost of debt, Cost of bank loans, Corporate governance.

Acknowledgments:

We thank three anonymous reviewers and seminar participants at the $41^{\text {st }}$ Annual Congress of the European Accounting Association in Milan (2018), the $19^{\text {th }}$ Workshop on Corporate Governance and Investment at Palma de Mallorca (2014), the Graz University of Technology and the University of Twente for many useful comments on previous drafts of the paper. 


\section{Introduction}

A significant relationship exists between firms and politicians. Governments attempt to influence the policies and activities of firms and their economic environment by means of regulations and taxes. In turn, firms develop specific strategies to manage and benefit from this environment. They build and nurture relationships with the government in power. They embrace the policies of certain political parties, make financial contributions to political establishments, and hire politicians or bureaucrats to become board members. Maintaining political connections has become an important component of corporate non-market strategies to compete with other firms. All these activities are widely prevalent not only in emerging countries but also in developed countries. Some scholars argue that political connections are more prominent in emerging countries due to imperfections in formal institutions, such as low investor protection, low legal enforcement and poor governance (Dinç, 2005; Faccio, 2006; Fisman, 2001).

Two strands of literature exist on the impact of political connections. The first strand consists of studies that show political connections deliver a variety of benefits to firms, for example, securing government bailouts (Faccio, Masulis, and McConnell, 2006) and procurement contracts (Goldman, Rocholl, and So, 2013), facing fewer regulatory investigations, prosecutions and penalties (Correia, 2014), and providing useful board monitoring (PascualFuster and Crespí-Cladera, 2018). Khwaja and Mian (2005) observe that politically connected firms enjoy greater access to financial resources from government banks. Dinç (2005) shows that state-owned banks increase their lending in election years relative to that of private banks. Similarly, Claessens, Feijen, and Laeven (2008) find that firms that make political donations obtain more bank financing after elections. Beck, Demirgüç-Kunt, and

Levine (2006) observe that in countries with poor law enforcement, politicians and bureaucrats utilize their power to influence banks in providing more financial access to firms. Political connections also help firms to obtain favorable credit terms. Bliss and Gul (2012) and Houston, Jiang, and Lin (2014) show that banks charge a lower rate for borrowing to politically connected firms. Finally, Boubakri, Guedhami, Mishra, and Saffar (2012b) and 
Joni, Ahmed, and Hamilton (2020) document that investors require a lower cost of equity from politically connected firms.

The second strand of literature includes studies that underline harmful effects of political connections. Shleifer and Vishny (1994) argue that politicians may influence firms to take inefficient decisions which are contrary to the principle of firm value maximization. They favor increasing employment and wages, especially prior to elections, to gain political support. Firms are also asked to produce goods that are preferred by politicians. In exchange, firms expect favorable policies in the form of subsidies or reducing tax liabilities. Bertrand, Kramarz, Schoar, and Thesmar (2018) provide supporting evidence as they observe that firms managed by politically connected CEOs exhibit higher employment growth in election years. Wang (2015) finds that politically connected independent directors help in wealth expropriation of minority investors. Habib, Muhammadi, and Jiang (2017) also report that related party transactions used by politically connected firms tunnel resources and hurt the interests of minority investors. Fan, Wong, and Zhang (2007) observe that newly privatized firms with politically connected CEOs experience long-term underperformance. Similarly, Chen, Li, Luo, and Zhang (2017) document a decline in the value of state-owned enterprises having higher political connections. Finally, Chaney, Faccio, and Parsley (2011) document a low earnings quality of politically connected firms. All these studies expose the dark side of maintaining political connection.

MacNeil (1978) posits that an organization develops relationship with other entities by using either transactional or relational approach. While a transactional approach involves shortterm relationship and focuses on issues individually, a relational approach is developed based on long-term objective. In this study, we examine whether the approach to developing and maintaining political connection matters for firms. When a government is in power for a long time, firms are motivated to develop a long-term relationship with the political establishment that is based on loyalty, trust and commitment. In contrast, when there is doubt about a political regime remaining in power, firms may prefer to develop short-term relationships and focus on issue-by-issue basis. Following such a transactional approach during times of 
frequent changes in political regime requires relatively less investment by firms but provides a more certain outcome.

Since the benefits and costs of a firm's political connection can depend on the approach it adopts, we attempt to investigate the economic effects of these two approaches. We specifically focus on a firm's cost of debt because debt contracting is more likely to be intervened by politicians, and non-commercial considerations such as political connection can help firms to increase their bargaining power and negotiate more favorable credit terms.

We analyze a sample of firms from Indonesia because the combination of changes towards democratization in the post-Suharto era and the new institutional context provides an interesting setting to investigate how firms develop their strategies in relation to political connections. ${ }^{1}$ Several institutional reforms leading to decentralization and democratization were introduced after the Suharto era. Legal reforms in relation to bureaucracy and the political system provided a more distributed structure of political power, and refined the role of parliament as a legislative institution. Power was distributed across regions and the president had to share power with other political institutions at various levels. Significant changes in the political system and the more frequent regime changes have led to more varied political patrons and modes of political engagement (Carney and Hamilton-Hart, 2015). Firms therefore needed to reshape their political connections when governments change. They also found it more complicated to develop relationships with a new regime. Leuz and Oberholzer-Gee (2006) report that Indonesian firms that had close relationship with the Suharto regime for more than three decades experienced poor long-term performance following his departure and faced significant difficulties in re-establishing the connection with the new political regime (e.g., President Wahid).

\footnotetext{
${ }^{1}$ Different regimes have been in power subsequent to the Suharto regime. President Habibie was in office for about a year and the country experienced changes due to several reform initiatives. In October 1999, President Wahid came to power by getting support from the MPR (people's and regional representative council). But, in July 2001, he was replaced by Vice-President Soekarnoputri after being impeached by the MPR. In October 2004, President Yudhoyono became the first directly elected president in Indonesia. He was re-elected after five years. President Widodo won the national election in July 2014 and has remained in office until now.
} 
By disentangling the effects of transactional and relational approaches to political connections, we provide a new contribution to the extant literature. To the best of our knowledge, no study has yet examined political connections from this angle. Our study is also important for a few other reasons. While previous studies on political connections in Indonesia focused solely on the autocratic Suharto era (Fisman, 2001; Leuz and OberholzerGee, 2006; Dieleman and Sachs, 2008), we examine the post-Suharto democratic era, which offered a more appealing political environment. During this period, political regimes changed frequently, and firms were motivated to constantly develop their political networks. Our study also involves a more comprehensive analysis of political connections covering the largest number of Indonesian firms to date. Furthermore, we use a continuous measure of political connection (instead of the commonly used binary indicator variable) which allows us to undertake a statistically more eloquent analysis.

By tracing the different waves of power changes in Indonesia, we show that debtholders value political connections in different ways. Transactionally connected firms experience a lower cost of debt than those following a relational strategy. When political regimes change frequently, a transactional approach facilitates firms becoming implicitly protected against adverse circumstances. Debtholders therefore adjust the required risk premium and reduce the interest rate on debt. Relational connection is valuable only when firms have connections with the regime in power. We also find that firms facing high financial distress enjoy a greater reduction in the cost of debt when they follow transactional rather than relational political connection. These results are robust to the use of cost of bank loans (loan spread) as an alternative measure and a variety regression methods to mitigate endogeneity between political connection and the cost of debt as well as the omitted variables bias. Additionally, we find that banks that do not have any political connection provide preferential lending to transactionally connected firms, and the transactional approach affects cost of borrowing by reducing agency costs. Overall, our findings indicate that the transactional approach to political connection is beneficial for firms during the period of political regime changes. 
The rest of the paper proceeds as follows. Section 2 discusses the hypotheses of our study. In Section 3, we describe the research methodology, variables and data. Sections 4 discusses the results and additional tests. The final section presents the conclusions of the paper.

\section{Hypothesis development}

Researchers are not unanimous on how lenders consider the effects of political connection on firm's debt contract. On the one hand, politically connected firms are perceived to be more risky than their counterparts due to higher leverage and a greater likelihood of reporting losses (Bliss and Gul, 2012). Politically connected firms often end up taking inefficient and unprofitable decisions and typically suffer from underperformance. Therefore, such firms tend to be charged higher interest rates by lenders. On the other hand, politically connected firms have higher probability of government protection and bailout in the event of financial distress and are therefore perceived to be less risky (Faccio et al., 2006). Commercial banks recognize these beneficial effects of political connections and provide favorable loans to these firms.

Given the costs and benefits of connections between firms and politicians, and the frequent changes in the political regime in Indonesia, it has become necessary for firms to choose an appropriate approach in developing political connections. Using a framework introduced by Macneil (1978) on the categorization of relationships, and further discussed by Rousseau and Parks (1993), we classify business-politician relationship into transactional and relational political connections.

A transactional political connection (TPC) is short-term in nature with the sole focus on how to cope with single issues or transactions. Such a relationship requires limited involvement by both parties and is perceived by firms as more flexible and efficient in dealing with politicians during times of frequent changes of political regimes. Firms have the ability to relatively easily adjust their political network so that it fits to the current regime. Given a relatively short time frame and single issue focus, a firm's involvement is limited in terms of necessary skills, resources and loyalties. Both parties thus have the flexibility to negotiate 
the terms of working together, and even the freedom to terminate the relationship if specific requirements or objectives are not met. ${ }^{2} \mathrm{~A}$ deterioration in a political partner's ability to provide resources increases the chance of a firm finding an alternative partner who can provide a better fit and good solution to solve their issues. Hence, TPC is more favorable when regime changes are expected to be more frequent. ${ }^{3}$ Adjusting to the current regime is necessary to enhance a firm's political network. By using a transactional strategy, firms are more likely to choose their political connections that are valuable and capable to provide favorable results. Firms typically work on an issue-by-issue basis; they aim for certain outcomes from their political connections and seek to minimize the risk of rent extraction by their political partner. ${ }^{4}$ Creditors have the capabilities and resources to identify the value of a firm's political connections such as providing implicit insurance against default risk or enjoying softer budget constraint (Houston et al., 2014; Boubakri et al., 2012b). While setting up a debt contract, they incorporate the fact that these firms have greater access to the current political regime and thus charge a lower interest rate.

On the other hand, a relational political connection (RPC) is governed by trust, good faith and long-term objectives. Firms continue to maintain connection with a political regime for a long period because they share the same political ideology. Relational connection thus involves a firm's commitment and loyalty to achieve a sustainable relationship with the politicians. A mutually beneficial relationship creates an incentive for both sides to continue the relationship over time. This conjecture is consistent with the findings of Kroszner and

\footnotetext{
${ }^{2}$ Following Rousseau and Parks (1993), we argue that TPC can serve as a trial contract to minimize risk before identifying appropriate partners for long-term arrangements. As an example, consider the case of PT Freeport Indonesia, a copper and gold mining company which appointed Maroef Sjamsoeddin, a former military and government spy agency chief, as president director in 2015. He resigned after a year in office following a political scandal in which the former House Speaker Setyo Novanto had allegedly demanded Freeport's shares from Maroef in exchange for helping with the extension of the firm's mining contract. He tried to negotiate with and lobby Setyo Novanto in order to get the extension as early as possible. Initially, the negotiation failed [http://thediplomat.com/2016/01/us-mining-giant-chief-in-indonesia-resigns-amid-uncertainty/; last accessed 9 January, 2017]. Later in December 2018, after two years of negotiation, the company obtained an extension of operating licence until 2041 [https://setkab.go.id/en/freeport-divesment-finalized-special-mining-businesslicence-replaces-contract-of-work/; last accessed 7 March, 2020].

${ }^{3}$ Lobbying on specific issues, a politician serving as a board member during one regime, and a one-time political donation are typical examples of TPC.

${ }^{4}$ The ultimate goal of politicians is to remain in power by winning re-elections. As long as there is no free lunch in the business-politics relationship, and political competition becomes costly due to democratization, the politician's incentive to extract firm’s resources for private benefit also increases.
} 
Stratmann (2005) who suggest that firms provide repeated political donations to legislators in the hope of increasing acceptance (refusal) of favorable (unfavorable) government policies and supporting other favors in the future. Continuous donations to a political party or politicians serving as board members across different regimes are representative examples of RPC. However, the investment in achieving and maintaining relational connection can be more costly to a firm when the political regime changes and the firm expects to receive less benefits over the long run.

In sum, a transactional political connection is more flexible and efficient in dealing with politicians in times of frequent changes in political regimes. Creditors recognize a firm's greater access to the current political regime and the value of this political connection; so, they charge a lower interest rate while setting up the debt contract. However, at times of frequent regime changes, firms may not find it worthwhile to continue a long-term relationship with one particular administration. Creditors also recognize that the firm with relational political connection will in the end receive fewer benefits. As a result, they are less likely to provide a greater reduction in interest rate. Therefore, our first hypothesis is:

H1: When political regimes change frequently, firms with transactional political connections incur a lower cost of debt than those with relational political connections.

To identify the channel through which approaches to political connections affect cost of debt, we investigate the relation between financial distress and cost of debt. The cost of financing increases when a firm's default risk increases. Creditors require a greater risk premium to compensate for the higher default risk and therefore charge a higher interest rate. Financially distressed firms find it difficult to increase their borrowing capacity since their cost of debt is high. These firms can use their access to the political network to reduce the detrimental effect of distress. Houston et al. (2014) suggests that that political connections provide implicit protection to a firm from low tail risk and dramatic changes in future credit risk. A financially distressed firm with transactional political connection has better access to the political network linked to the current regime. Creditors consider the greater implicit insurance effect and are willing to charge a lower rate. We therefore conjecture that 
transactional political connection leads to a greater reduction in the cost of debt by reducing the detrimental effects of financial distress.

On the other hand, a distressed firm with relational political connection is less likely to benefit from access to the current political regime. Relational political connections lose their influence when a new political regime takes power. These connections will be unable to implicitly insure firms that face a high likelihood of a default. Creditors will not value firm's relational connections when setting up a new debt contract when political regimes change quickly.

Consequently, we formulate the following hypothesis:

H2: When political regimes change frequently, firms with transactional political connections enjoy a greater reduction in the cost of debt as their financial distress levels increase relative to those with relational connections.

\section{Empirical Framework}

\subsection{Model}

To examine the effect of transactional and relational political connections on the cost of debt, we estimate the following two Ordinary Least Squares (OLS) regression model:

$$
\begin{aligned}
& C O D_{i t}=\alpha_{0}+\beta_{1} \operatorname{TPC}_{i t-1}+\sum_{j=1}^{J} \beta_{j} X_{i t-1}+\eta_{t}+v_{t}+\epsilon_{i t} \\
& C O D_{i t}=\alpha_{0}+\beta_{1} R P C_{i t-1}+\sum_{j=1}^{J} \beta_{j} X_{i t-1}+\eta_{t}+v_{t}+\epsilon_{i t}
\end{aligned}
$$

where $C O D_{i t}$ is the cost of debt for firm $i$ in year $t-1$; TPC and RPC represent the measure of the firm's transactional and relational political connections; $\mathrm{X}$ is a vector of firm-specific control variables; $\eta_{\mathrm{t}}$ and $v_{\mathrm{t}}$ are year and industry fixed effects, respectively. To partially 
mitigate potential endogeneity effects (Aslan 2016; Hasan, Hoi, Wu, and Zhang, 2014), and to consider the fact that credit contracts are partially affected by borrowers' past credit performance, we use one year lagged values for the firm characteristics. Regarding the first hypothesis, we expect the estimated regression coefficient of transactional political connection $\left(\beta_{1}\right)$ to be more negative than that of relational political connection.

We check the robustness of OLS regressions by employing several empirical methods: probit regressions, generalized least square random effect (GLS-RE) regressions, Heckman twostages regressions, and propensity score matching (PSM). We use probit regression to examine the likelihood that TPC or RPC will have a cost of debt lower than their industry median. One advantage of GLS-RE estimation technique is that the impact of our main explanatory variables, TPC and RPC, which are relatively time-invariant, can be estimated efficiently. ${ }^{5}$ We conduct Heckman two-stages regression and propensity score matching analysis to alleviate any concern that firms' political connection is endogenously determined, and the OLS estimation suffers from the omitted variables bias.

The second hypothesis examines whether the risk of financial distress can affect the relationship between political connection and the cost of debt. The multivariate regression specifications to test the hypothesis are written below:

$$
\begin{aligned}
\operatorname{COD}_{i t}=\alpha_{0}+ & \beta_{1} \text { TPC }_{i t-1}+\beta_{2} \text { Distress }_{i t-1}+\beta_{3} \text { TPC }_{i t-1} * \text { Distress }_{i t-1} \\
& +\sum_{j=1}^{J} \beta_{j} X_{i t-1}+\eta_{t}+v_{t}+\epsilon_{i t} \\
\text { COD }_{i t}=\alpha_{0}+ & \beta_{1} \text { RPC }_{i t-1}+\beta_{2} \text { Distress }_{i t-1}+\beta_{3} \text { RPC }_{i t-1} * \text { Distress }_{i t-1}
\end{aligned}
$$

\footnotetext{
${ }^{5}$ Since the political connection variable does not vary much over time, the standard fixed-effect panel estimation is not suitable for our study (Wooldridge, 2002, p. 286). Fixed-effect estimation requires the independent variable to have within-firm variation to obtain efficient and consistent estimations. Relatively time invariant variable, e.g. political connection, cannot be estimated with fixed-effect estimation as it would be absorbed in time-demeaning process of variables in fixed-effect. Several studies also employ GLS-RE when they have relatively time-invariant independent variable, such as CEO characteristics (Pathan, 2009) and creditor rights (Bae and Goyal, 2009).
} 


$$
+\sum_{j=1}^{J} \beta_{j} X_{i t-1}+\eta_{t}+v_{t}+\epsilon_{i t}
$$

Since the cost of debt is expected to be higher for firms with higher risks of financial distress, the $\beta_{2}$ coefficient should be positive. The moderating role of financial distress is examined through the interaction terms of political connection and financial distress. The coefficient of interest, $\beta_{3}$, is expected to be negative because we hypothesize that firms facing higher financial distress can enjoy a greater reduction in the cost of debt if they have transactional political connections.

All our regressions include a set of control variables related to firm characteristics. Larger firms tend to be more diversified and have less information asymmetry. Therefore, larger firms are expected to face a lower cost of debt. Similarly, firms with higher liquidity and growth opportunity have a greater ability to pay both interest and principal, and therefore incur a lower cost of debt. Older firms tend to have a stronger reputation and a longer track record; debtholders are therefore expected to charge lower interest rates. Finally, intangible assets create more information asymmetry, thereby increasing the agency cost of debt; hence, the cost of debt increases. For a sub-sample of firms for which information about their bank loans is available, we undertake regressions that also control for loan characteristics.

\subsection{Variable measurement}

\subsubsection{Cost of debt}

Like most other countries, the great majority of Indonesian firms do not issue bonds that are listed on a stock exchange. Therefore, we follow previous studies (Bauwhede, Michiel, and Cauwenberge, 2015; Bliss and Gul, 2012; Francis, LaFond, Olsson, and Schipper, 2005; Minnis, 2011) that use the interest payment information disclosed in financial statements to calculate the cost of debt. We estimate the interest rate as the ratio of a firm's annual interest payments to its total debt. Since this measure has the limitation that it largely reflects the historical cost of debt, we use for a sub-sample of firms, the current yield spread - the amount a firm pays in basis points over LIBOR or LIBOR equivalent - as an alternate proxy. 


\subsubsection{Political connection}

Publicly listed firms in Indonesia are required to disclose biographical information about their board members in their annual reports. A firm is identified as politically connected if at least one board member is a current or former minister, member of parliament, government official or some other politician. We manually collect this information and cross-check with company, stock exchange and government websites. ${ }^{6}$ Previous studies (e.g., Faccio, 2006; Chaney et al., 2011; Joni et al., 2020) also used this method to capture firms' political connections. ${ }^{7}$ We categorize relational (transactional) connection if a board member had (had not) stayed in office for more than one term and across two political regimes. Information on the start and finish dates of all board members is collected to determine the duration of each board membership. In the regression analysis, we use the proportion of politically connected board members by counting the number of transactional or relational politically connected board members and dividing it by the total number of board members.

\subsubsection{Other variables}

As mentioned earlier, we include a large number of control variables in the regression model. We use the debt-coverage ratio, estimated as operating income divided by short-term debt, as a measure of firm's financial distress (DISTRESS). A higher debt coverage ratio indicates a lower probability of distress; it is expected to have a negative relationship with the cost of debt. ${ }^{8}$ Firm size (SIZE) is calculated as the book value of total assets. Investment in property, plant and equipment (PPE) is estimated as a proportion of total assets. Variables representing liquidity (CASH) and intangible assets (INTANG) are estimated as the proportions of cash and intangibles assets, respectively. Firm age (AGE) is calculated as the number of years

\footnotetext{
${ }^{6}$ The government websites are: Cabinet of Republic of Indonesia (www.set-kab.go.id/en/profil-kabinet.html), local government officials (www.kemendagri.go.id/staff-directory/gubernur-dan-wakil-gubernur), and House of Representatives at the national level (www.dpr.go.id/id/anggota/) and the local level.

${ }^{7}$ Prior studies measure political connections in different ways like the political background of large shareholders (Faccio, 2006; Khwaja and Mian, 2005; Goldman, Rocholl, and So, 2013; Nys, Tarazi, Trinugroho, 2015), campaign contributions (Hersch and McDougall, 2000; Kroszner and Stratmann, 2005), and lobbying efforts (Correia, 2014; Unsal, Hassan, and Zirek, 2016). Information on these measures is not publicly available for Indonesian firms.

${ }^{8}$ We also use three additional variables - short-term debt to total assets ratio, long-term debt maturing within a year, and Altman's Z-score - as alternate proxy of financial distress. Since the regression results are qualitatively similar, we do not present these results seperately in the paper.
} 
since listing on the stock exchange. Growth opportunity (GROWTH) is calculated as the market value of the equity divided by the book value of the equity. Foreign ownership (FOR) is a dummy variable that takes the value of one if the ultimate owner is a foreign company or institution, and zero otherwise. ${ }^{9}$

Table 1 presents the definitions and measurements of all the variables used in the study.

[Insert Table 1 here]

\subsection{Data}

We initially select all the Indonesian public firms listed on the Jakarta stock exchange during 2007-2016. This time-period is chosen for two reasons. First, our focus is to investigate how firms develop their political connections during the decentralized and democratized era after the Suharto regime. Second, the data about the listed firms in Indonesia are available in ORBIS database from 2007 onwards. We exclude firms operating only in the financial sector because these are heavily regulated by the government and have a specific financial structure. We collect all necessary data, in particular information on the amount of interest paid, debt, assets, cash, intangibles assets, foreign ownership, and SIC industry classifications. The number of firms in the sample varies from 284 firms in 2007 to 424 in 2016. In total, our sample consists of 3,907 firm-year observations, making it the largest sample of Indonesian firms analyzed to date. The sample is dominated by manufacturing firms, representing about $40 \%$ of the sample. The next important industrial sectors are transportation \& communication, real estate and services. We also collect information on bank loans from the DealScan database. This information is available for a small number of firms (44 firms).

\footnotetext{
${ }^{9}$ In an additional analysis, we control for the concentrated ownership of Indonesian firms by considering a new dummy variable that equals one if a firm has at least one shareholder owning $25 \%$ of voting rights or more.
} 


\section{Results}

\subsection{Univariate analysis}

We first winsorize all variables at $5 \%$ to mitigate potential outlier problems. The summary statistics of the key variables are presented in Panel A of Table 2. The mean cost of debt of the sample firms is 3.8\%. It is almost equal to that estimated by Joni et al. (2020) for Indonesian firms, but lower than the 5.6\% reported by Bliss and Gul (2012) for politically connected firms in Malaysia during the post-Asian financial crisis period (2001-2004).

There are 197 firms (46\%) in our sample that have political connections in 2016. About 80\% of these firms follow the transactional political connection (TPC) approach while $10 \%$ of the firms have relational political connections (RPC). ${ }^{10}$ The remaining $10 \%$ of the sample of firms have both types of political connections.

[Insert Table 2 here]

Considering the full sample of firms, we find that the average proportion of board members in transactionally politically connected firms is $8.7 \%$ while the corresponding figure for RPC firms is just $1.1 \%$. For a sub-sample of firms, we collect information on bank loan characteristics. The average (median) spread is 341 (325) basis points. The average loan facility amount is $\$ 168$ million, and the maturity is 50 months. In addition, $25 \%$ of loan facilities are secured by collateral.

\footnotetext{
${ }^{10}$ Two examples can describe the difference between these two approaches. First, a transactional politically connected firm is PT Bentoel International Investama where Djoko Muljono, a former Senior Adviser of the Ministry of Trade and Industry was appointed as board commissioner for four years, from 2008 until 2012. A change of political regime took place in 2009. Muljono was later replaced by Eddy Abdurrahman, a former Director of General of Customs and Excise in the Ministry of Finance. Second, a relational politically connected firm is PT Matahari Putra Prima. This retail company had Jonathan Parapak, a formerly Secretary General in the Ministry of Tourism, Arts and Culture, as board commissioner for more than ten years, from 2000 until 2013. He survived two different political regimes.
} 
Panel B of Table 2 presents the correlation matrix of the major variables used in the regression analysis. TPC is negatively correlated with the cost of debt, whereas RPC has a statistically insignificant correlation with it. We observe that operating income to currentdebt ratio (DISTRESS), cash (CASH), firm size (SIZE), growth opportunity (GROWTH), firm age (AGE), foreign ownership (FOR) and audit quality (AUD) are negatively correlated with the cost of debt. In contrast, property, plant, and equipment (PPE) and intangible assets (INTANG) are positively correlated with the cost of debt.

We estimate the cost of debt of firms along the high and low financial distress spectrums and the two political connection approaches. The univariate test statistics show that the cost of debt of the sub-sample of firms with a higher likelihood of financial distress is significantly lower for TPC firms (4.5\%) than non-TPC firms (4.8\%). The differences in the cost of debt of the RPC firms in either the high- or low-distress categories are statistically insignificant. We obtain similar results when we use yield spread to measure the cost of bank loans.

\subsection{Regression results}

We begin the multivariate analysis by performing pooled ordinary least square regressions. We report results of all the regressions with clustered standard errors at the firm level. Table 3 reports the regression results. First, we analyze the effect of political connections (PC) in general without differentiating TPC and RPC. Model (1) shows that the coefficient of PC is negative and statistically significant at the $1 \%$ level. The finding indicates that politically connected firms pay 0.85 percentage points lower cost of debt than their non-connected counterparts.

When we separate sample firms into TPC and RPC sub-samples, we observe that in Model (2) the coefficient of TPC is more negative and statistically significant at the $1 \%$ level. The effect of TPC is not only statistically significant, but also economically significant. The coefficient estimate indicates that a one standard deviation increase in transactional

politically connected board membership leads to a reduction of 0.28 percentage points in the cost of debt. With the average total debt of \$292 million, one standard deviation increase in 
TPC results in a reduction of US $\$ 803.3$ thousands in interest paid. ${ }^{11}$ Model (3) result shows that the impact of relational political connection (RPC) on the cost of debt is statistically insignificant. The result is in sharp contrast with the decline in cost of debt found for transactional politically connected firms.

[Insert Table 3 here]

We perform a similar analysis of the politically connected firms only. The regression result presented in Model 4 shows that the estimated coefficient of TPC is negative and statistically significant at the 1\% level, whereas in Model 5 the coefficient of RPC is statistically insignificant. The result is consistent with our previous finding: firms that develop transactional political connections enjoy lower cost of debt than firms with relational connections. The same result holds when we re-estimate the model with probit and generalized least square random effect regressions. ${ }^{12}$ Overall, the regression results support the first hypothesis that transactional political connection provides a greater reduction in cost of debt than the relational one. The finding indicates that the relational political connection strategy becomes less valuable in times of frequent regime changes.

As the relational approach is maintained across different political regimes, this connection can become outdated and powerless in one specific regime but can be valuable if firms have connections with the current political regime. We collect information on board members who are connected to the same institution/organization as that of the president and vice-president and then examine whether these connections provide additional benefit to firms. We also analyze a variable representing the interaction between relational political connection and the number of connections with the current president or vice president. The results show that relational political connection becomes valuable in reducing the cost of debt when firms have

\footnotetext{
${ }^{11}$ The detailed calculation is as follows: the standard deviation TPC is 0.131 and the estimated coefficient of TPC in Table 3 is 0.021 . Thus, a one standard deviation increase in TPC leads to a reduction in interest rate by 0.28 percentage points $(-0.021 \times 0.131)$. The total decline in interest paid per year is $\$ 292$ million $\mathrm{x} 0.002751$ $=\$ 803.3$ thousands.

${ }^{12}$ We use a probit model to estimate the likelihood of politically connected firms to have lower cost of debt than the industry median. A dummy variable for cost of debt is created, with value of one if the interest rate is above median industry, and zero otherwise. An advantage of GLS-RE is that the impact of political connections, which are relatively time-invariant, can be estimated efficiently.
} 
connection with the current political regime. ${ }^{13}$ Not surprisingly, we observe that TPC firms enjoy more reduction in cost of debt if they also develop connection with the current political regime. We also examine the value of political connections with the military, ministry of finance and government banks. The results show that connections with military are valuable in reducing the cost of debt, whereas the connections with ministry of finance or government banks have no effect. ${ }^{14}$ This result also suggests that the nature of political connections plays an important role in providing value for firms in reducing cost of debt.

To test whether firms in financial distress benefit from a lower cost of debt if they have either transactional or relational political connections, we run the cost of debt regressions and specifically focus on the interaction terms between political connections and financial distress. These results are reported in Table 4. We find that the estimated regression coefficients of the interaction term TPC $\times$ DISTRESS in Models (1) and (2) are positive and statistically significant. ${ }^{15}$ To better understand the magnitude of the effect, we consider for example Model (2) that incorporates all control variables, and multiply the interaction coefficient by the standard deviation of TPC. The result indicates that a one standard deviation increase in transactional politically connected board membership additionally reduces the average interest rate of high distress firms by 0.80 percentage points relative to low distress firms. When we estimate similar regressions for firms with relational political connections (Models 3 and 4), we do not find significant interaction coefficients for RPC $\times$ DISTRESS. ${ }^{16}$ Hypothesis two is therefore supported.

[Insert Table 4 here]

\footnotetext{
${ }^{13}$ Due to space consideration, we do not present these and some other results in separate tables. These tables are availale from the authors upon request.

14 The military still dominates the political scene in Indonesia. In presidential election from 2004 until 2019, at least one of the presidential candidates were former military candidates.

${ }^{15}$ A positive interaction coefficient means that the effect of the combined action of two predictors is stronger then the sum of the individual effects.

${ }^{16}$ We observe similar result when we use other proxies to measure financial distress such as Altman Z-Score, short-term debt to total assets ratio, and long-term debt maturing within a year to total assets ratio.
} 


\subsection{Robustness tests}

\subsubsection{Endogeneity and omitted factors}

Our empirical analysis might suffer from endogeneity between political connection and the cost of debt as well as the omitted variables bias (firms might become politically active based on unobserved characteristics that also affect the cost of debt). To rule out these concerns, we use Heckman two-stages correction model and propensity score matching technique.

In employing Heckman two-stages correction model, we use a probit model in the first stage to estimate the probability of firms being transactional or relational politically connected as a function of firm characteristics. We use two instrumental variables to predict transactional or relational political connection: geographic location of the firm's headquarters (Boubakri et al., 2012a; Houston et al., 2014) and the political connection of other firms within the same industry (Hersch and McDougall, 2000; Schuler, Rehbien, and Cramer, 2002). Based on the first-stage, we calculate the Inverse Mills ratio (IMR) and include it in the second-stage regression. The results of the second-stage estimation are presented in Table 5. We observe that in Model (2), the TPC coefficients is negative and statistically significant at the $1 \%$ level. When we regress the cost of debt on the interaction of TPC $\times$ DISTRESS, we observe a positive and statistically significant coefficient at the $1 \%$ level. The finding suggests that firms with financial distress enjoy a greater reduction in the cost of debt if they follow transactional political connection. On the other hand, the estimation results of Model (4) show that the interaction coefficient RPC * DISTRESS is statistically insignificant. We do not find any evidence that relational connected firms experience any change in cost of debt during financial distress.

[Insert Table 5 here]

One can argue that the two instruments we use are not perfectly suited to control for endogeneity. An alternative could be to use the propensity score matching (PSM) technique in which the treatment and control groups are required to be similar across firm characteristics except for the dependent variable, the cost of debt. First, we use the propensity 
score obtained from probit estimation and perform caliper and Gaussian kernel to match our sample. In the matched sample, we find that both treatment and control groups have similar characteristics (untabulated). The results presented in Panel A of Table 6 show that the cost of debt of firms with transactional political connections is significantly lower at the $1 \%$ level in both caliper and Gaussian kernel methods. Using bootstrap with 100 replications also provide consistent results. In contrast, the results in Panel B show that firms with the relational political connection have higher cost of debt.

We also report the results based on Entropy balancing techniques proposed by Hainmueller (2012). This preprocessing technique involves reweighting observations to achieve covariates balances in the first three moments. This method ensures that the treatment (politically connected) and control (non-politically connected) groups are similar in terms of mean, standards deviation, and skewness. This estimation strengthens the findings of PSM, and supports our main premise that transactional political connections are more beneficial during frequent regime changes.

[Insert Table 6 here]

\subsubsection{Cost of bank loans}

Our measure of cost of debt uses annual interest payment information and does not capture the current yield spread. For a sub-set of 44 firms for which bank loans data are available, we perform new regressions by using the natural logarithm of yield spread. We control for firm and loan characteristics and incorporate year, industry, loan-type, and loan-purpose fixed effects in the regression. The results are presented in Table 5. In Models (1) and (2), we find that the estimated regression coefficients of TPC and TPC_Dummy are negative and statistically significant at the $1 \%$ and $10 \%$ level, respectively. The finding suggests that firms with transactional political connection pay on average lower spread on bank loans than other firms. Model (1) shows that a one standard deviation increase in transactional politically connected board membership (13.1 percentage points) leads to a reduction of 4.53 basis points $(341 \times 0.1013 \times 0.131)$ of loan spread. With the average sample loan size of US\$168 million and average loan's time maturity of around four years, this reduction in interest cost 
amounts to US\$303.7 thousands $(168$ million $\times 0.000452 \times 4)$. Interestingly, we observe from Models (3) and (4) that the cost of bank loans is significantly higher for firms following relational political connection. Overall, the results support our premise that, when political regimes frequently change, transactional politically connection is more beneficial than relational political connection. ${ }^{17}$

[Insert Table 7 here]

\subsection{Additional analysis}

\subsubsection{Channels through which political connections affect cost of bank loans}

Houston et al. (2014) identify two channels - borrower channel and bank channel - through which political connections can affect firm's debt pricing. The borrower channel explains how creditors, at the time of setting up the debt contract, recognize a firm's potential benefits of political connection. Creditors also provide implicit insurance against any unfavorable condition the firm faces such as the emergence of financial distress. Our second hypothesis essentially corresponds to the borrower channel. The bank channel, on the other hand, posits that creditors provide favorable loan terms to politically connected firms in order to develop indirect political connection for themselves so that they can also potentially gain some benefits. Houston et al. (2014) argue that the bank channel may exist in developing countries where politicians can relatively easily intervene in the operations of commercial banks. When political regimes change frequently, our conjecture is that banks without any political connection provide favorable loans to firms that have transactional political connection. To examine this conjecture, we conduct a new analysis by interacting non-politically connected banks with firm's political connections (TPC and RPC). The results are presented in Table 8. In Model (1), we see that the coefficient of TPC is negative and statistically significant at the $1 \%$ level. The positive and statistically significant coefficient of the interaction term (TPC $\times$ Non-PC Bank) suggests that non-politically-connected banks provide favorable loans to TPC firms. On the other hand, Model (2) result shows that the interaction coefficient of RPC

\footnotetext{
${ }^{17}$ Analyzing the effects on non-price terms of bank loans (e.g., collateral and loan size) shows that TPC firms have lower collateral requirement and larger loan size relative to RPC firms.
} 
$\times$ Non-PC Bank is statistically insignificant. The finding indicates that non-politicallyconnected banks do not provide favorable loans to RPC firms. These results support the bank channel argument.

[Insert Table 8 here]

\subsubsection{Influence of agency costs}

The agency theory can be used to explain the relationship between firms and politicians, with firms acting as the principal and the politicians as the agent (Getz, 2002). Firms attempt to use politicians/bureaucrats to adopt favorable policies and get preferential access to government resources. Chaney et al. (2011) argue that while firms enjoy these benefits from their connections, they have less incentive to provide high quality information disclosure. We posit that lenders consider the different value of approaches to political connections in compensating information asymmetry when setting up the debt contract. Information asymmetry between lender and borrower can create agency costs and lead to adjustments in the debt contract including higher interest rate. The transactional political connection can alleviate the lender's concern on the future profitability of firm. However, this may not be the case for relational political connection where there is less certain outcome for firms. We test this conjecture and present the regression results in Table 9. Using two measure of information asymmetry, accounting accruals and stock return volatility, as proxy for agency costs, we find that in Models (1) and (3), the coefficients of interaction terms TPC $\times$ AGENCYCOSTS are negative and statistically significant at the $10 \%$ level. However, we find insignificant results for the interaction terms of RPC $\times$ AGENCYCOSTS in Models (2) and (4). These results support our main hypothesis that TPC firms enjoy more benefits relative to RPC firms.

[Insert Table 9 here]

\subsubsection{Impact on firm value and cost of equity}

Our empirical analysis yields a robust evidence on the value of transactional political connections in reducing the cost of debt. We further investigate whether these two political 
connections affect firm value and cost of equity. Prior research indicates that political connections affect firm value through several channels: change in expected cash flow, e.g., subsidies, bailout, tax saving; and/or change in the discount rate, e.g., cost of capital (Boubakri et al., 2012b). Given the different implications of TPC and RPC as discussed above, we argue that TPC has a greater impact on firm value than RPC. Using Tobin's Q as a measure of firm value, the results (untabulated) reveal that transactional politically connected firms experience positive and significant increase in firm value. This increase in firm value might reflect preferential access to debt financing, lower taxes, or subsidies. In contrast, we observe an insignificant effect of relational political connection.

Next, we examine the effect of TPC and RPC on the cost of equity capital. Transactional and relational connections differ in nature of their objectives, agency relations, or expropriation risks, which may lead to differences perceptions of shareholders. The estimation of a firm's cost of equity is usually confronted with methodological problems. One approach is to use stock market data and employ the Capital Asset Pricing Model (Joni et al., 2020). Because of multiple problems associated with proper estimation of the CAPM, many scholars use accounting and earnings forecasts data and estimate the implied cost of equity (Boubakri et al., 2012b; Guedhami et al., 2014). We use four different methods to estimate the implied cost of equity (Gebhardt, Lee, and Swaminathan; 2001; Claus and Thomas, 2001; Easton, 2004; and Ohlson and Juettener-Nauroth, 2005) as well as the average estimate. Earnings forecasts data from the Institutional Brokers Earnings Services (I/B/E/S) database for the period 2007-2016 are available for only a limited number of Indonesian firms (195 firm-year observations). ${ }^{18}$ The results (untabulated) show that the estimated coefficients for TPC and RPC are statistically insignificant across all regression models. The two approaches to political connections do not appear to influence the cost of equity capital. The statistically insignificant result can be due to a small number of observations. Another explanation could be that shareholders realize that the benefits of either transactional or relational connections do not exceed the costs.

${ }^{18}$ The sample analyzed by Boubakri et al. (2012b) consists of only 8 firm-year observations from Indonesia. 


\subsubsection{Impact of ownership concentration}

Although the regression results of our study control for foreign ownership, other types of owners, especially, large shareholders can play an influential role as well. Following Guedhami et al. (2014), we also examine whether the value of political connections varies across different level of ownership concentration. We investigate this effect by including in the regression model the interaction between political connection variables and a dummy variable to represent concentrated ownership (shareholder owning $25 \%$ or more of voting rights). The corresponding empirical results (untabulated) show that the coefficient of the interaction terms between ownership concentration and transactional political connection is positive and significant. The estimation suggests that the effect of transactional political connection on the cost of debt is stronger in firms with more concentrated ownership. Interestingly, we also find a significant effect for the relational politically-connected firms. Concentrated ownership thus helps to attenuate agency problems between owner and managers. Large shareholders have higher incentive and better ability to monitor managers by reducing the expropriation risk of politically-connected boards.

\section{Conclusions}

Using a framework on the categorization of contracts introduced by Macneil (1978) and further discussed by Rousseau and Parks (1993), we classify business - politician relationship into transactional and relational political connections and examine its impact on firm's cost of debt. We study these approaches to political connections in Indonesia during the postSuharto democratic era where political regimes changed frequently and it became important for firms to constantly maintain a link with the current regime.

Analyzing a sample of publicly listed firm in Indonesia, we find that firms with transactional political connection exhibit a lower cost of debt. In contrast, a relational political connection has no statistically significant impact on a firm's cost of debt. We find similar results using cost of bank loans as an alternative proxy and a large variety of alternative regression methods (probit, generalized least-squares random effects, Heckman two-stages, propensity score matching and Entropy balancing method). Overall, these robustness tests indicate that 
firms with transactional political connection experience a significantly lower cost of debt than their counterparts. This effect is stronger for firms with higher financial distress. The finding supports the view that transactional political connection helps to increase the implicit insurance of riskier firms, and creditors reward these firms by reducing the interest rate they charge. In times of frequently changing political regimes, it is beneficial for a firm to follow a transactional relationship with the politicians. Specific problems facing the firm can be solved relatively easily because of the issue-by-issue focus. Firms can even terminate and develop new political connections when specific objectives are not fulfilled. We also find that firms that engage in a transactional political connection enjoy lower volatility in cost of debt.

The empirical evidence provided in this study supports the hypothesis that firms that are transactionally (politically) connected enjoy more reduction in cost of debt than relationally connected firms. Firms' capabilities to adjust their political connection to the current political regime enhance their access to a greater political network. Moreover, developing a transactional political connection might minimize the rent-seeking incentives and expropriations by the politicians. On the other hand, developing a relational political connection that is usually governed by good faith and trust might provide uncertain benefits for firms in case of frequent regime changes. Creditors recognize the advantage of transactional political connections and value this implicit insurance through their credit pricing, thus charging a lower cost of debt. Overall, this paper contributes to the extant literature by providing an interesting angle to explore the outcome of alternative approaches to political connections.

The finding of this study have important implications for practice. We demonstrate how businesses can make it conducive by adapting their approaches to develop and maintain political connection. Corporate managers and directors therefore need to revisit their strategy on political ties based on expected changes in government in power. Because transactional political connections are valued higher by creditors when political regimes change, the regulators also need to take extra care towards potential intervention in debt contracting, especially when a country's law enforcement is relatively weak. Governments of emerging 
countries should strengthen law enforcement and improve bank supervision mechanism to mitigate political intervention in financial institutions.

Our study can be extended in several ways. Data considerations restrict us to focus on the political affiliation of board members. Alternative proxies for political connections (for example, political links of large owners, lobbying and political donations) could provide robust evidence. In addition, examining political connections in more specific settings (for example, firms under legal investigation of tax offices or capital market regulatory institutions) might improve our understanding of different effects. This research could also be a baseline for further studies examining other dimensions of political connections, such as local or regional level connections. Finally, extending this study to other countries with different political systems would be challenging and interesting. 


\section{References}

Aslan, H., 2016. Do lending relationship affect corporate financial policies? Financial Management 45 (1), 141-173.

Bae, K., Goyal, V. K., 2009. Creditor rights, enforcement, and bank loans. The Journal of Finance, 64 (2), 823-861.

Bauwhede, H. V., Meyere, M. D., Cauwenberge, P. V., 2015. Financial reporting quality and the cost of debt of SMEs. Small Business Economics 45 (1), 149-164.

Beck, T., Demirgüç-Kunt, A., Levine, R., 2006. Bank supervision and corruption in lending. Journal of Monetary Economics 53 (8), 2131-2163.

Bertrand, M., Kramarz, F., Schoar, A., Thesmar, D., 2018. The cost of political connections. Review of Finance 22 (3), 849-876.

Bliss, M. A., Gul, F. A., 2012. Political connection and cost of debt: Some Malaysian evidence. Journal of Banking and Finance 36 (5), 1520-1527.

Boubakri, N., Cosset, J. C., Saffar, W., 2012a. The impact of political connections on firms' operating performance and financing decisions. Journal of Financial Research 35 (3), 397-423.

Boubakri, N., Guedhami O., Mishra D., Saffar, W., 2012b. Political connections and the cost of equity capital. Journal of Corporate Finance 18 (3), 541-559.

Carney, R. W., Hamilton-Hart, N., 2015. What do changes in corporate ownership in Indonesia tell us? Bulletin of Indonesian Economic Studies 51 (1), 123-145.

Chaney, P. K., Faccio, M., Parsley, D., 2011. The quality of accounting information in politically connected firms. Journal of Accounting and Economics 51 (1-2), 58-76.

Chen, J., King, T. D., 2014. Corporate hedging and the cost of debt. Journal of Corporate Finance 29, 221-245.

Chen, C., Li, Y., Luo, D., Zhang, T., 2017. Helping hands or grabbing hands? An analysis of political connections and firm value. Journal of Banking and Finance 80, 71-89.

Claessens, S., Feijen, E., Laeven, L., 2008. Political connections and preferential access to finance: The role of campaign contributions. Journal of Financial Economics 88 (3), $554-580$. 
Claus, J., Thomas, J., 2001. Equity premia as low as three percent? Evidence from analysts' earnings forecasts for domestic and international stock markets. Journal of Finance 56, 1629-1666.

Correia, M. M., 2014. Political connections and SEC enforcement. Journal of Accounting and Economics 57 (2-3), 241-262.

Dieleman, M., Sachs, W. M., 2008. Coevolution of institutions and corporations in emerging economies: How the Salim Group morphed into an institution of Suharto's crony regime. Journal of Management Studies 45 (7), 1274-1300.

Dinç, I. S., 2005. Politicians and banks: Political influences on government-owned banks in emerging markets. Journal of Financial Economics 77 (2), 453-479.

Easton, P., 2004. PE ratios, PEG ratios, and estimating the implied expected rate of return on equity capital. Accounting Review 79, 73-95.

Faccio, M., 2006. Politically connected firms. The American Economic Review 96 (1), 369386.

Faccio, M., Masulis, R. W., McConnell, J. J., 2006. Political connections and corporate bailouts. Journal of Finance 61 (6), 2597-2635.

Fan, J. H., Wong, T. J., Zhang, T., 2007. Politically connected CEOs, corporate governance, and post-IPO performance of China's newly partially privatized firms. Journal of Financial Economics 84 (2), 330-357.

Fisman, R., 2001. Estimating the value of political connections. The American Economic Review 91 (4), 1095-1102.

Francis, J., LaFond, R., Olsson, P., Schipper, K., 2005. The market pricing of accruals quality. Journal of Accounting and Economics 39 (2), 295-327.

Gebhardt, W., Lee, C., Swaminathan, B., 2001. Towards an implied cost of capital. Journal of Accounting Research 39 (1), 135-176.

Getz, K., 2002. Public affairs and political strategy: Theoretical foundations. Journal of Public Affairs 1 (4), 305-329.

Goldman, E., Rocholl, J., So, J., 2013. Politically connected boards of directors and the allocation of procurement contracts. Review of Finance 17 (5), 1617-1648.

Goyal, V. K., 2009. Creditor rights, enforcement, and bank loans. The Journal of Finance 64 (2), 823-861. 
Guedhami, O., Pittman, J. A., Saffar, W., 2014. Auditor choice in politically connected firms. Journal of Accounting Research 52 (1), 107-162.

Habib, A., Muhammadi, A. H., Jiang, H., 2017. Political connections and related party transactions: Evidence from Indonesia. The International Journal of Accounting 52, 45-63.

Hainmueller, J., 2012. Entropy balancing for causal effects: A multivariate reweighting method to produce balanced samples in observational studies. Political Analysis 20 (1), 25-46.

Hamadi, M., Heinen, A., 2015. Firm performance when ownership is very concentrated: Evidence from a semiparametric panel. Journal of Empirical Finance 34, 172-194.

Hasan, I., Hoi, C. K., Wu, Q., Zhang, H., 2014. Beauty is in the eye of the beholder: The effect of corporate tax avoidance on the cost of bank loans. Journal of Financial Economics 113 (1), 109-130.

Hersch, P. L., McDougall, G. S., 2000. Determinants of automobile PAC contributions to House Incumbents: Own versus rival effects. Public Choice 104 (3/4), 329-343.

Hillman, A. J., Hitt, M. A., 1999. Corporate political strategy formulation: A model of approach, participation, and strategy decisions. Academy of Management Review 24 (4), 825-842.

Houston, J. F., Jiang, L., Lin, C., Ma, Y., 2014. Political connections and the cost of bank loans. Journal of Accounting Research 52 (1), 193-243.

Joni, J., Ahmed, K., Hamilton, J., 2020. Politically connected boards, family and business group affiliations, and cost of capital: Evidence from Indonesia. The British Accounting Review 52 (3), 100878.

Khwaja, A. I., Mian, A., 2005. Do lenders favor politically connected firms? Rent provision in an emerging financial market. The Quarterly Journal of Economics 120 (4), 13711411.

Kotter, J. P., 1979. Managing external dependence. The Academy of Management Review 4 (1), 87-92.

Kroszner, R. S., Stratmann, T., 2005. Corporate campaign contributions, repeat giving, and the rewards to regislator reputation. The Journal of Law and Economics 48 (1), 41-71. 
Leuz, C., Oberholzer-Gee, F., 2006. Political relationships, global financing, and corporate transparency: Evidence from Indonesia. Journal of Financial Economics 81 (2), 411439.

Macneil, I. R., 1978. Contracts: Adjustment of long-term economic relations under classical, neoclassical, and relational contract law. Northwestern University Law Review 72 (6), 854-905.

Minnis, M., 2011. The value of financial statement verification in debt financing: Evidence from private U.S. firms. Journal of Accounting Research 49 (2), 457-506.

Nys, E., Tarazi, A., Trinugroho, I. 2015. Political connections, bank deposits, and formal deposit insurance. Journal of Financial Stability 19, 83-104

Ohlson, J., Juettner-Nauroth, B., 2005. Expected EPS and EPS growth as determinants of value. Review Accounting Studies 10, 349-365.

Pascual-Fuster, B., Crespí-Cladera,R., 2018. Politicians in the boardroom: Is it a convenient burden? Corporate Governance: An International Review 26 (6), 393-470.

Pathan, S., 2009. Strong boards, CEO power and bank risk-taking. Journal of Banking and Finance 33 (7), 1340-1350.

Rousseau, D. M., Parks, J. M., 1993. The contracts of individals and organizations. Research in Organizational Behavior 15, 1-43.

Schuler, D. A., Rehbien, K., Cramer, R. D., 2002. Pursuing strategic advantage through political means : A multivariate approach. The Academy of Management Journal 45 (4), 659-672.

Shleifer, A., Vishny, R. W., 1986. Large shareholders and corporate conntrol. Journal of Political Economy 94 (3), 461-488.

Shleifer, A., Vishny, R. W., 1994. Politicians and firms. The Quarterly Journal of Economics 109 (4), 995-1025.

Unsal, O., Hassan, M. K., Zirek, D., 2016. Corporate lobbying, CEO political ideology and firm performance. Journal of Corporate Finance 38, 126-149

Wang, L., 2015. Protection or expropriation: Politically connected independent directors in China. Journal of Banking \& Finance 55, 92-106.

Wooldridge, J. M., 2002. Econometric analysis of cross section and panel data. MIT Press, Cambridge, Massachussetts, London. 
Table 1. Variable definitions

\begin{tabular}{|c|c|}
\hline Variables & Description \\
\hline Cost of debt (COD) & Interest paid divided by total debt. \\
\hline Loan spread (SPREAD) & $\begin{array}{l}\text { All-in-drawn spread, which are the basis points paid in excess of the } \\
\text { London Interbank Offered Rate (LIBOR) or LIBOR equivalent; the } \\
\text { natural logarithm is used in regressions. }\end{array}$ \\
\hline Loan size (LOANSZ) & The loan facility amount; the natural logarithm is used in regressions. \\
\hline $\begin{array}{l}\text { Loan maturity } \\
\text { (MATURITY) }\end{array}$ & $\begin{array}{l}\text { The maturity period of the bank loan stated in years; the natural } \\
\text { logarithm is used in regressions. }\end{array}$ \\
\hline $\begin{array}{l}\text { Collateral } \\
\text { (COLLATERAL) }\end{array}$ & $\begin{array}{l}\text { Dummy variable equal to one if the loan requires collateral, and zero } \\
\text { otherwise. }\end{array}$ \\
\hline $\begin{array}{l}\text { Transactional political } \\
\text { connection (TPC) }\end{array}$ & $\begin{array}{l}\text { The number of board members classified as transactional political } \\
\text { connection divided by the total number of board members. }\end{array}$ \\
\hline $\begin{array}{l}\text { Relational political } \\
\text { connection (RPC) }\end{array}$ & $\begin{array}{l}\text { The number of board members classified as relational political } \\
\text { connections divided by the total number of board members. }\end{array}$ \\
\hline $\begin{array}{l}\text { Financial distress } \\
\text { (DISTRESS) }\end{array}$ & Operating income divided by short-term debt. \\
\hline Firm size (SIZE) & $\begin{array}{l}\text { The book value of total assets; the natural logarithm is used in } \\
\text { regressions. }\end{array}$ \\
\hline $\begin{array}{l}\text { Property, Plant, and } \\
\text { Equipment (PPE) }\end{array}$ & $\begin{array}{l}\text { Net investment in property, plant, and equipment scaled by the book } \\
\text { value of total assets. }\end{array}$ \\
\hline Inventory (INV) & Net inventory scaled by the book value of total assets. \\
\hline Cash (CASH) & Cash and equivalent cash scaled by the book value of total assets. \\
\hline $\begin{array}{l}\text { Intangible assets } \\
\text { (INTANG) }\end{array}$ & Intangible assets scaled by the book value of total assets. \\
\hline $\begin{array}{l}\text { Growth opportunity } \\
\text { (GROWTH) }\end{array}$ & Market value of equity divided by the book value of equity. \\
\hline Firm age (AGE) & Years since initial public offering. \\
\hline Audit quality (AUD) & $\begin{array}{l}\text { Dummy variable equal to one if the firm audited by Big } 4 \text { auditors, } \\
\text { and zero otherwise. }\end{array}$ \\
\hline $\begin{array}{l}\text { Foreign ownership } \\
\text { (FOR) }\end{array}$ & $\begin{array}{l}\text { Dummy variable equal to one if the ultimate owner is a foreign } \\
\text { company or institution, and zero otherwise. }\end{array}$ \\
\hline
\end{tabular}




\section{Table 2. Descriptive statistics and correlation matrix}

Panel A: Descriptive statistics

The table shows the descriptive statistics of main variables used in the study. All variables are defined in Table 1.

\begin{tabular}{|c|c|c|c|c|c|c|}
\hline Variable & $\mathrm{N}$ & Mean & SD & P25 & P50 & P75 \\
\hline COD & 3630 & 0.038 & 0.027 & 0.016 & 0.035 & 0.056 \\
\hline ТPC & 3388 & 0.087 & 0.131 & 0 & 0 & 0.143 \\
\hline RPC & 3388 & 0.011 & 0.04 & 0 & 0 & 0 \\
\hline DISTRESS & 3907 & 30.133 & 60.931 & 3.019 & 6.948 & 19.051 \\
\hline PPE & 3907 & 0.346 & 0.24 & 0.146 & 0.308 & 0.538 \\
\hline CASH & 3907 & 0.093 & 0.092 & 0.02 & 0.06 & 0.138 \\
\hline SIZE (US\$ million) & 3907 & 525 & 1,300 & 42.70 & 140.00 & 443.00 \\
\hline INTANG & 3907 & 0.010 & 0.025 & 0 & 0 & 0.003 \\
\hline GROWTH & 3466 & 1.881 & 1.835 & 0.592 & 1.179 & 2.558 \\
\hline AGE & 3486 & 13.344 & 7.753 & 6 & 14 & 19 \\
\hline FOR & 3405 & 0.214 & 0.410 & 0 & 0 & 0 \\
\hline AUD & 3738 & 0.078 & 0.268 & 0 & 0 & 0 \\
\hline \multicolumn{7}{|l|}{ Bank loan characteristics } \\
\hline SPREAD (basis points) & 138 & 341 & 145 & 230 & 325 & 400 \\
\hline Collateral & 167 & 0.25 & 0.44 & 0 & 0 & 1.00 \\
\hline Loan size (US\$ million) & 166 & 168 & 164 & 55 & 122 & 215 \\
\hline Maturity (months) & 161 & 50 & 24 & 36 & 60 & 60 \\
\hline
\end{tabular}




\section{Panel B: Correlation matrix}

The table shows the Pearson correlation coefficients of major variables for the full sample of firms. All variables are defined in Table 1. Boldface indicates statistical significance at the 5 percent level.

\begin{tabular}{|c|c|c|c|c|c|c|c|c|c|c|c|c|}
\hline & $(1)$ & (2) & (3) & (4) & (5) & (6) & (7) & (8) & (9) & (10) & (11) & (12) \\
\hline COD (1) & 1 & & & & & & & & & & & \\
\hline TPC (2) & -0.090 & 1 & & & & & & & & & & \\
\hline RPC (3) & 0.036 & 0.008 & 1 & & & & & & & & & \\
\hline DISTRESS (4) & -0.266 & 0.006 & -0.005 & 1 & & & & & & & & \\
\hline PPE (5) & 0.202 & 0.012 & 0.014 & -0.145 & 1 & & & & & & & \\
\hline CASH (6) & -0.208 & 0.098 & -0.049 & 0.250 & -0.248 & 1 & & & & & & \\
\hline SIZE (7) & -0.057 & 0.208 & -0.052 & -0.012 & 0.031 & 0.174 & 1 & & & & & \\
\hline INTANG (8) & 0.076 & 0.051 & -0.068 & 0.021 & -0.080 & 0.061 & 0.204 & 1 & & & & \\
\hline GROWTH (9) & -0.090 & 0.053 & 0.024 & 0.162 & -0.045 & 0.184 & 0.113 & 0.078 & 1 & & & \\
\hline AGE (10) & -0.176 & 0.000 & -0.003 & 0.085 & -0.009 & -0.081 & 0.042 & -0.154 & -0.076 & 1 & & \\
\hline FOR (11) & -0.140 & -0.107 & -0.009 & 0.115 & 0.047 & 0.010 & 0.080 & 0.051 & 0.081 & 0.207 & 1 & \\
\hline AUD (12) & -0.040 & -0.028 & 0.004 & 0.032 & 0.062 & 0.018 & 0.171 & 0.016 & 0.017 & 0.068 & 0.109 & 1 \\
\hline
\end{tabular}


Table 3. The effect of transactional and relational political connections on the cost of debt

This table presents the ordinary least square (OLS) regression results of the cost of debt on transactional and relational political connections. All variables are defined in Table 1 . The t-statistics, reported in parentheses, are based on clustered standard errors at the firm level.

\begin{tabular}{|c|c|c|c|c|c|}
\hline & \multicolumn{3}{|c|}{ Full sample } & \multicolumn{2}{|c|}{ PC firms } \\
\hline & (1) & (2) & (3) & (4) & (5) \\
\hline $\mathrm{PC}_{(\mathrm{t}-1)}$ & $\begin{array}{c}-0.017^{* * *} \\
(-3.00)\end{array}$ & & & & \\
\hline $\mathrm{TPC}_{(\mathrm{t}-1)}$ & & $\begin{array}{c}-0.021^{* * *} \\
(-3.43)\end{array}$ & & $\begin{array}{l}-0.018^{*} \\
(-2.06)\end{array}$ & \\
\hline $\mathrm{RPC}_{(\mathrm{t}-1)}$ & & & $\begin{array}{l}0.023 \\
(1.06)\end{array}$ & & $\begin{array}{l}0.026 \\
(0.90)\end{array}$ \\
\hline DISTRESS $_{(\mathrm{t}-1)}$ & $\begin{array}{c}-0.000^{* * *} \\
(-7.81)\end{array}$ & $\begin{array}{c}-0.000^{* * *} \\
(-7.77)\end{array}$ & $\begin{array}{c}-0.000^{* * *} \\
(-7.87)\end{array}$ & $\begin{array}{c}-0.000^{* * *} \\
(-4.64)\end{array}$ & $\begin{array}{c}-0.000^{* * *} \\
(-4.78)\end{array}$ \\
\hline $\operatorname{PPE}_{(\mathrm{t}-1)}$ & $\begin{array}{l}0.012^{* *} \\
(2.64)\end{array}$ & $\begin{array}{l}0.012^{* *} \\
(2.61)\end{array}$ & $\begin{array}{l}0.012^{*} \\
(2.58)\end{array}$ & $\begin{array}{l}0.009 \\
(1.45)\end{array}$ & $\begin{array}{l}0.010 \\
(1.50)\end{array}$ \\
\hline $\mathrm{CASH}_{(\mathrm{t}-1)}$ & $\begin{array}{c}-0.033^{* *} \\
(-3.07)\end{array}$ & $\begin{array}{c}-0.032^{* *} \\
(-2.99)\end{array}$ & $\begin{array}{c}-0.034^{* *} \\
(-3.21)\end{array}$ & $\begin{array}{l}-0.022 \\
(-1.45)\end{array}$ & $\begin{array}{l}-0.024 \\
(-1.54)\end{array}$ \\
\hline INTANG $_{(t-1)}$ & $\begin{array}{l}0.052 \\
(1.65)\end{array}$ & $\begin{array}{l}0.053 \\
(1.71)\end{array}$ & $\begin{array}{l}0.054 \\
(1.71)\end{array}$ & $\begin{array}{c}0.082 \\
(1.91)\end{array}$ & $\begin{array}{l}0.082 \\
(1.90)\end{array}$ \\
\hline $\operatorname{SIZE}_{(t-1)}$ & $\begin{array}{l}0.000 \\
(0.40)\end{array}$ & $\begin{array}{l}0.000 \\
(0.53)\end{array}$ & $\begin{array}{l}0.000 \\
(0.05)\end{array}$ & $\begin{array}{l}0.001 \\
(0.56)\end{array}$ & $\begin{array}{l}0.000 \\
(0.29)\end{array}$ \\
\hline GROWTH $_{(\mathrm{t}-1)}$ & $\begin{array}{l}-0.001 \\
(-1.40)\end{array}$ & $\begin{array}{l}-0.001 \\
(-1.39)\end{array}$ & $\begin{array}{l}-0.001 \\
(-1.47)\end{array}$ & $\begin{array}{l}-0.001 \\
(-1.97)\end{array}$ & $\begin{array}{l}-0.001 \\
(-1.95)\end{array}$ \\
\hline $\operatorname{AGE}_{(t-1)}$ & $\begin{array}{c}-0.003^{* *} \\
(-3.26)\end{array}$ & $\begin{array}{c}-0.003^{* *} \\
(-3.23)\end{array}$ & $\begin{array}{c}-0.004^{* * *} \\
(-3.36)\end{array}$ & $\begin{array}{c}-0.005^{* * *} \\
(-3.14)\end{array}$ & $\begin{array}{c}-0.005^{* * *} \\
(-3.25)\end{array}$ \\
\hline $\operatorname{AUD}_{(\mathrm{t}-1)}$ & $\begin{array}{l}-0.002 \\
(-0.79)\end{array}$ & $\begin{array}{l}-0.002 \\
(-0.89)\end{array}$ & $\begin{array}{l}-0.001 \\
(-0.65)\end{array}$ & $\begin{array}{l}-0.002 \\
(-0.58)\end{array}$ & $\begin{array}{l}-0.002 \\
(-0.57)\end{array}$ \\
\hline $\mathrm{FOR}_{(\mathrm{t}-1)}$ & $\begin{array}{l}-0.006^{*} \\
(-2.59)\end{array}$ & $\begin{array}{c}-0.007^{* *} \\
(-2.66)\end{array}$ & $\begin{array}{l}-0.006^{*} \\
(-2.32)\end{array}$ & $\begin{array}{l}-0.004 \\
(-1.10)\end{array}$ & $\begin{array}{l}-0.002 \\
(-0.65)\end{array}$ \\
\hline Constant & $\begin{array}{c}0.052^{* * *} \\
(4.18)\end{array}$ & $\begin{array}{c}0.051^{* * *} \\
(4.07)\end{array}$ & $\begin{array}{c}0.055^{* * *} \\
(4.25)\end{array}$ & $\begin{array}{l}0.045^{* *} \\
(2.46)\end{array}$ & $\begin{array}{l}0.047^{* *} \\
(2.52)\end{array}$ \\
\hline Year FE & Yes & Yes & Yes & Yes & Yes \\
\hline Industry FE & Yes & Yes & Yes & Yes & Yes \\
\hline Observations & 1997 & 1997 & 1997 & 922 & 922 \\
\hline Adjusted $R^{2}$ & 0.203 & 0.206 & 0.196 & 0.176 & 0.169 \\
\hline
\end{tabular}




\section{Table 4. The joint effect of political connection and financial distress on the cost of debt}

This table presents the OLS regression results of the cost of debt on transactional and relational political connections conditional on financial distress. All variables are defined in Table 1. The t-statistics, reported in parentheses, are based on clustered standard errors at the firm level.

\begin{tabular}{|c|c|c|c|c|}
\hline & (1) & (2) & (3) & (4) \\
\hline $\mathrm{TPC}_{(\mathrm{t}-1)}$ & $\begin{array}{c}-0.023^{* * *} \\
(-3.53)\end{array}$ & $\begin{array}{c}-0.028^{* * *} \\
(-4.12)\end{array}$ & & \\
\hline $\operatorname{TPC}_{(\mathrm{t}-1)} \times \operatorname{DISTRESS}_{(\mathrm{t}-1)}$ & $\begin{array}{c}0.001^{* * *} \\
(2.95)\end{array}$ & $\begin{array}{c}0.001^{* * *} \\
(3.34)\end{array}$ & & \\
\hline $\mathrm{RPC}_{(\mathrm{t}-1)}$ & & & $\begin{array}{l}0.031 \\
(1.28)\end{array}$ & $\begin{array}{l}0.030 \\
(1.24)\end{array}$ \\
\hline $\operatorname{RPC}_{(\mathrm{t}-1)} \times \operatorname{DISTRESS}_{(\mathrm{t}-1)}$ & & & $\begin{array}{l}-0.001 \\
(-1.02)\end{array}$ & $\begin{array}{l}-0.001 \\
(-1.27)\end{array}$ \\
\hline $\operatorname{DISTRESS}_{(\mathrm{t}-1)}$ & $\begin{array}{c}-0.000^{* * *} \\
(-12.27)\end{array}$ & $\begin{array}{c}-0.000^{* * * *} \\
(-8.46)\end{array}$ & $\begin{array}{c}-0.000^{* * *} \\
(-10.70)\end{array}$ & $\begin{array}{c}-0.000^{* * *} \\
(-7.40)\end{array}$ \\
\hline $\operatorname{PPE}_{(\mathrm{t}-1)}$ & & $\begin{array}{l}0.012^{* *} \\
(2.72)\end{array}$ & & $\begin{array}{l}0.012^{*} \\
(2.56)\end{array}$ \\
\hline $\mathrm{CASH}_{(\mathrm{t}-1)}$ & & $\begin{array}{c}-0.031^{* *} \\
(-2.88)\end{array}$ & & $\begin{array}{c}-0.034^{* *} \\
(-3.15)\end{array}$ \\
\hline $\operatorname{INTANG}_{(\mathrm{t}-1)}$ & & $\begin{array}{l}0.053^{*} \\
(1.71)\end{array}$ & & $\begin{array}{l}0.054^{*} \\
(1.69)\end{array}$ \\
\hline $\operatorname{SIZE}_{(t-1)}$ & & $\begin{array}{l}0.000 \\
(0.56)\end{array}$ & & $\begin{array}{l}0.000 \\
(0.05)\end{array}$ \\
\hline $\mathrm{GROWTH}_{(\mathrm{t}-1)}$ & & $\begin{array}{l}-0.001 \\
(-1.44)\end{array}$ & & $\begin{array}{l}-0.001 \\
(-1.47)\end{array}$ \\
\hline $\operatorname{AGE}_{(t-1)}$ & & $\begin{array}{c}-0.003^{* *} \\
(-3.22)\end{array}$ & & $\begin{array}{c}-0.004^{* * *} \\
(-3.33)\end{array}$ \\
\hline $\operatorname{AUD}_{(\mathrm{t}-1)}$ & & $\begin{array}{l}-0.002 \\
(-0.93)\end{array}$ & & $\begin{array}{l}-0.002 \\
(-0.69)\end{array}$ \\
\hline $\mathrm{FOR}_{(\mathrm{t}-1)}$ & & $\begin{array}{c}-0.007^{* * *} \\
(-2.63)\end{array}$ & & $\begin{array}{c}-0.006^{* *} \\
(-2.29)\end{array}$ \\
\hline Constant & $\begin{array}{c}0.051^{* * *} \\
(11.18)\end{array}$ & $\begin{array}{c}0.051^{* * *} \\
(4.14)\end{array}$ & $\begin{array}{c}0.048^{* * *} \\
(10.45)\end{array}$ & $\begin{array}{c}0.055^{* * *} \\
(4.24)\end{array}$ \\
\hline Year FE & Yes & Yes & Yes & Yes \\
\hline Industry FE & Yes & Yes & Yes & Yes \\
\hline Observations & 2443 & 1997 & 2443 & 1997 \\
\hline Adjusted $R^{2}$ & 0.151 & 0.211 & 0.141 & 0.196 \\
\hline
\end{tabular}


Table 5. The effect of political connection on the cost of debt: Heckman two-stages analysis

This table presents the second-stage results of Heckman two-stages analysis for the effect of approaches to political connections on the cost of debt. The first-stage regression estimates the likelihood of the firm having TPC or RPC. Based on the first-stage, we calculate the Inverse Mills ratio (IMR) and include it in the secondstage regression. The variable definitions are presented in Table 1. The t-statistics, reported in parentheses, are based on clustered standard errors at the firm level.

\begin{tabular}{|c|c|c|c|c|}
\hline & 1 & 2 & 3 & 4 \\
\hline $\mathrm{TPC}_{(\mathrm{t}-1)}$ & $\begin{array}{c}-0.021^{* * *} \\
(-3.45)\end{array}$ & $\begin{array}{c}-0.028^{* * *} \\
(-4.15)\end{array}$ & & \\
\hline $\operatorname{TPC}_{(\mathrm{t}-1)} \times \operatorname{DISTRESS}_{(\mathrm{t}-1)}$ & & $\begin{array}{c}0.001^{* * *} \\
(3.38)\end{array}$ & & \\
\hline $\mathrm{RPC}_{(\mathrm{t}-1)}$ & & & $\begin{array}{l}0.024 \\
(1.07)\end{array}$ & $\begin{array}{l}0.030 \\
(1.26)\end{array}$ \\
\hline $\operatorname{RPC}_{(\mathrm{t}-1)} \times \operatorname{DISTRESS}_{(\mathrm{t}-1)}$ & & & & $\begin{array}{l}-0.001 \\
(-1.31)\end{array}$ \\
\hline $\operatorname{DISTRESS}_{(\mathrm{t}-1)}$ & $\begin{array}{c}-0.001^{* * *} \\
(-7.83)\end{array}$ & $\begin{array}{c}-0.001^{* * *} \\
(-8.53)\end{array}$ & $\begin{array}{c}-0.001^{* * *} \\
(-7.93)\end{array}$ & $\begin{array}{c}-0.001^{* * *} \\
(-7.46)\end{array}$ \\
\hline $\mathrm{PPE}_{(\mathrm{t}-1)}$ & $\begin{array}{l}0.012^{* *} \\
(2.64)\end{array}$ & $\begin{array}{l}0.012^{* *} \\
(2.75)\end{array}$ & $\begin{array}{l}0.012^{* *} \\
(2.61)\end{array}$ & $\begin{array}{l}0.012^{* *} \\
(2.59)\end{array}$ \\
\hline $\mathrm{CASH}_{(\mathrm{t}-1)}$ & $\begin{array}{c}-0.032^{* * *} \\
(-3.02)\end{array}$ & $\begin{array}{c}-0.031^{* *} \\
(-2.90)\end{array}$ & $\begin{array}{c}-0.034^{* * * *} \\
(-3.23)\end{array}$ & $\begin{array}{c}-0.034^{* * *} \\
(-3.17)\end{array}$ \\
\hline INTANG $_{(\mathrm{t}-1)}$ & $\begin{array}{l}0.053^{*} \\
(1.70)\end{array}$ & $\begin{array}{l}0.052^{*} \\
(1.69)\end{array}$ & $\begin{array}{l}0.054^{*} \\
(1.70)\end{array}$ & $\begin{array}{l}0.053^{*} \\
(1.68)\end{array}$ \\
\hline $\operatorname{SIZE}_{(t-1)}$ & $\begin{array}{l}0.000 \\
(0.53)\end{array}$ & $\begin{array}{l}0.000 \\
(0.55)\end{array}$ & $\begin{array}{l}0.000 \\
(0.04)\end{array}$ & $\begin{array}{l}0.000 \\
(0.04)\end{array}$ \\
\hline GROWTH $_{(\mathrm{t}-1)}$ & $\begin{array}{l}-0.001 \\
(-1.39)\end{array}$ & $\begin{array}{l}-0.001 \\
(-1.44)\end{array}$ & $\begin{array}{l}-0.001 \\
(-1.46)\end{array}$ & $\begin{array}{l}-0.001 \\
(-1.46)\end{array}$ \\
\hline $\operatorname{AGE}_{(t-1)}$ & $\begin{array}{c}-0.003^{* * *} \\
(-3.26)\end{array}$ & $\begin{array}{c}-0.003^{* * *} \\
(-3.26)\end{array}$ & $\begin{array}{c}-0.004^{* * *} \\
(-3.40)\end{array}$ & $\begin{array}{c}-0.004^{* * *} \\
(-3.37)\end{array}$ \\
\hline $\operatorname{AUD}_{(\mathrm{t}-1)}$ & $\begin{array}{l}-0.002 \\
(-0.88)\end{array}$ & $\begin{array}{l}-0.002 \\
(-0.92)\end{array}$ & $\begin{array}{l}-0.001 \\
(-0.65)\end{array}$ & $\begin{array}{l}-0.002 \\
(-0.68)\end{array}$ \\
\hline $\mathrm{FOR}_{(\mathrm{t}-1)}$ & $\begin{array}{c}-0.007^{* *} \\
(-2.71)\end{array}$ & $\begin{array}{c}-0.007^{* *} \\
(-2.69)\end{array}$ & $\begin{array}{l}-0.006^{*} \\
(-2.37)\end{array}$ & $\begin{array}{l}-0.006^{*} \\
(-2.35)\end{array}$ \\
\hline IMR & $\begin{array}{l}-0.015 \\
(-0.55)\end{array}$ & $\begin{array}{l}-0.015 \\
(-0.53)\end{array}$ & $\begin{array}{l}-0.005 \\
(-0.20)\end{array}$ & $\begin{array}{l}-0.004 \\
(-0.19)\end{array}$ \\
\hline Constant & $\begin{array}{c}0.053^{* * *} \\
(4.29)\end{array}$ & $\begin{array}{c}0.054^{* * *} \\
(4.36)\end{array}$ & $\begin{array}{c}0.057^{* * *} \\
(4.48)\end{array}$ & $\begin{array}{c}0.057^{* * * *} \\
(4.47)\end{array}$ \\
\hline Year FE & Yes & Yes & Yes & Yes \\
\hline Industry FE & Yes & Yes & Yes & Yes \\
\hline Wald Chi2 & 306.06 & 339.18 & 305.55 & 316.94 \\
\hline Probability & 0.000 & 0.000 & 0.000 & 0.000 \\
\hline
\end{tabular}


Table 6. The effect of approaches to political connection on the cost of debt: Propensity score matching and Entropy balancing analysis

This table presents results from propensity score matching and Entropy balancing where firms with TPC/RPC are matched to firms without TPC/RPC. The matching starts with a probit regression in which the dependent variable is the presence of TPC or RPC and the explanatory variables are a group of firm characteristics that can potentially affect the political connections. We employ caliper matching with a caliper of 0.001 and Gaussian Kernel matching. For entropy balancing, the observations are weighted to equate means for out-ofbalance covariates between firms with TPC or RPC and those do not. The variable definitions are presented in Table 1.

Panel A. Transactional Political Connection

\begin{tabular}{|c|c|c|c|c|}
\hline Propensity Score Matching & \multicolumn{2}{|c|}{ Caliper } & \multicolumn{2}{|c|}{ Gaussian Kerne } \\
\hline $\begin{array}{l}\text { Difference in the } \\
\text { cost of debt }\end{array}$ & \multicolumn{2}{|c|}{$\begin{array}{c}-0.003^{* *} \\
(-2.18)\end{array}$} & \multicolumn{2}{|c|}{$\begin{array}{l}-0.003^{* *} \\
(-2.31)\end{array}$} \\
\hline & \multicolumn{2}{|c|}{ Caliper } & \multicolumn{2}{|c|}{ Gaussian Kernel } \\
\hline Bootstrapped 100 replications & Coeff. & z-stat & Coeff. & z-stat \\
\hline TPC & $-0.004^{* * *}$ & -3.19 & $-0.004^{* * *}$ & -3.13 \\
\hline Std. Err. & 0.001 & & 0.001 & \\
\hline Observations & 1922 & & 1922 & \\
\hline Entropy Balancing & Coeff. & t-stat & & \\
\hline TPC & $-0.004^{* * *}$ & -3.72 & & \\
\hline Control variables & Yes & & & \\
\hline Year FE & Yes & & & \\
\hline Industry FE & Yes & & & \\
\hline Observations & 1899 & & & \\
\hline$R^{2}$ & 0.221 & & & \\
\hline
\end{tabular}

Panel B. Relational Political Connection

\begin{tabular}{|c|c|c|c|c|}
\hline Propensity Score Matching & \multicolumn{2}{|c|}{ Caliper } & \multicolumn{2}{|c|}{ Gaussian Kernel } \\
\hline $\begin{array}{l}\text { Difference in the } \\
\text { cost of debt }\end{array}$ & \multicolumn{2}{|c|}{$\begin{array}{c}0.009^{* *} \\
(2.51)\end{array}$} & \multicolumn{2}{|c|}{$\begin{array}{c}0.005^{* *} \\
(2.13)\end{array}$} \\
\hline & \multicolumn{2}{|c|}{ Caliper } & \multicolumn{2}{|c|}{ Gaussian Kernel } \\
\hline Bootstrapped 100 replications & Coeff. & z-stat & Coeff. & z-stat \\
\hline RPC & 0.005 & 1.57 & 0.005 & $1.87^{*}$ \\
\hline Std. Err. & 0.003 & & 0.002 & \\
\hline Observations & 1922 & & 1922 & \\
\hline Entropy Balancing & Coeff. & t-stat & & \\
\hline RPC & $0.005^{* *}$ & 2.30 & & \\
\hline Control variables & Yes & & & \\
\hline Year FE & Yes & & & \\
\hline Industry FE & Yes & & & \\
\hline Observations & 1899 & & & \\
\hline$R^{2}$ & 0.221 & & & \\
\hline
\end{tabular}


Table 7. The effect of transactional and relational political connections on the cost of bank loans

This table presents the ordinary least square (OLS) regression results of the cost of bank loans on transactional and relational political connections. The dependent variable is the natural logarithm of yield spread, defined as the amount the borrower pays in basis points over LIBOR or LIBOR equivalent for each dollar drawn down. Because the spread variable reflects current yield spread, we do not use lag of political connection variables as in baseline model. LOANSZ is the natural logarithm of the loan facility amount in USD. MATURITY is the natural logarithm of the maturity period of the bank loan stated in years. Collateral is a dummy variable, with value of one when the loan requires collateral, and zero otherwise. All other variables are defined in Table 1.

\begin{tabular}{|c|c|c|c|c|}
\hline & $(1)$ & (2) & (3) & (4) \\
\hline $\mathrm{TPC}_{\mathrm{t}}$ & $\begin{array}{c}-9.511 * * * \\
(-4.162)\end{array}$ & & & \\
\hline TPC_DUMMY $_{t}$ & & $\begin{array}{l}-1.783^{*} \\
(-1.892)\end{array}$ & & \\
\hline $\mathrm{RPC}_{\mathrm{t}}$ & & & $\begin{array}{l}21.518^{*} \\
(1.695)\end{array}$ & \\
\hline RPC_DUMMY ${ }_{t}$ & & & & $\begin{array}{l}2.294^{*} \\
(1.970)\end{array}$ \\
\hline DISTRESS $_{\mathrm{t}}$ & $\begin{array}{l}0.003^{*} \\
(1.904)\end{array}$ & $\begin{array}{c}0.003^{* *} \\
(2.359)\end{array}$ & $\begin{array}{c}0.003^{* *} \\
(2.528)\end{array}$ & $\begin{array}{l}0.003^{* *} \\
(2.514)\end{array}$ \\
\hline $\mathrm{PPE}_{\mathrm{t}}$ & $\begin{array}{c}-0.314 \\
(-0.259)\end{array}$ & $\begin{array}{c}-0.622 \\
(-0.465)\end{array}$ & $\begin{array}{c}-0.313 \\
(-0.261)\end{array}$ & $\begin{array}{c}-0.606 \\
(-0.494)\end{array}$ \\
\hline $\mathrm{CASH}_{\mathrm{t}}$ & $\begin{array}{l}-9.483^{*} \\
(-1.827)\end{array}$ & $\begin{array}{c}-11.848^{* *} \\
(-2.403)\end{array}$ & $\begin{array}{c}-13.896 * * * \\
(-2.863)\end{array}$ & $\begin{array}{c}-13.874 * * * \\
(-2.954)\end{array}$ \\
\hline $\mathrm{SIZE}_{\mathrm{t}}$ & $\begin{array}{c}0.183 \\
(0.422)\end{array}$ & $\begin{array}{c}-0.071 \\
(-0.153)\end{array}$ & $\begin{array}{c}-0.514 \\
(-1.047)\end{array}$ & $\begin{array}{c}-0.484 \\
(-1.015)\end{array}$ \\
\hline INTANG $_{\mathrm{t}}$ & $\begin{array}{c}-6.382 \\
(-0.586)\end{array}$ & $\begin{array}{c}-3.651 \\
(-0.336)\end{array}$ & $\begin{array}{c}-7.742 \\
(-0.827)\end{array}$ & $\begin{array}{c}-6.300 \\
(-0.647)\end{array}$ \\
\hline $\mathrm{GROWTH}_{\mathrm{t}}$ & $\begin{array}{l}-0.008^{*} \\
(-1.709)\end{array}$ & $\begin{array}{l}-0.009 * \\
(-1.721)\end{array}$ & $\begin{array}{l}-0.010^{*} \\
(-1.949)\end{array}$ & $\begin{array}{l}-0.009 * \\
(-1.985)\end{array}$ \\
\hline $\mathrm{AGE}_{\mathrm{t}}$ & $\begin{array}{c}-0.527 \\
(-1.125)\end{array}$ & $\begin{array}{c}-0.500 \\
(-0.964)\end{array}$ & $\begin{array}{c}-0.677 \\
(-1.154)\end{array}$ & $\begin{array}{c}-0.653 \\
(-1.164)\end{array}$ \\
\hline $\mathrm{AUD}_{\mathrm{t}}$ & $\begin{array}{c}-0.965 \\
(-0.579)\end{array}$ & $\begin{array}{c}-1.941 \\
(-1.378)\end{array}$ & $\begin{array}{c}-2.523 \\
(-1.639)\end{array}$ & $\begin{array}{c}-2.368 \\
(-1.580)\end{array}$ \\
\hline $\mathrm{FOR}_{\mathrm{t}}$ & $\begin{array}{c}-1.246 \\
(-1.016)\end{array}$ & $\begin{array}{c}0.175 \\
(0.144)\end{array}$ & $\begin{array}{c}1.159 \\
(0.743)\end{array}$ & $\begin{array}{c}1.224 \\
(0.830)\end{array}$ \\
\hline LOANSZ $_{\mathrm{t}}$ & $\begin{array}{c}0.432 \\
(0.929)\end{array}$ & $\begin{array}{c}0.266 \\
(0.553)\end{array}$ & $\begin{array}{c}0.399 \\
(0.812)\end{array}$ & $\begin{array}{c}0.421 \\
(0.901)\end{array}$ \\
\hline MATURITY $_{\mathrm{t}}$ & $\begin{array}{c}0.145 \\
(0.917)\end{array}$ & $\begin{array}{c}0.164 \\
(0.962)\end{array}$ & $\begin{array}{c}0.151 \\
(0.940)\end{array}$ & $\begin{array}{c}0.150 \\
(0.931)\end{array}$ \\
\hline Constant & Yes & Yes & Yes & Yes \\
\hline Industry FE & Yes & Yes & Yes & Yes \\
\hline Loan-Type FE & Yes & Yes & Yes & Yes \\
\hline Loan-Purpose FE & Yes & Yes & Yes & Yes \\
\hline No. of Loan Facilities & 138 & 138 & 138 & 138 \\
\hline No. of Firms & 44 & 44 & 44 & 44 \\
\hline Adjusted $R^{2}$ & 0.548 & 0.523 & 0.515 & 0.527 \\
\hline
\end{tabular}


Table 8. Channels through which political connections affect cost of bank loans

This table presents the pooled ordinary least square regression results of banks with and without political connections. The dependent variable is the natural logarithm of Spread. Spread is the all-in spread drawn, defined as the amount the borrower pays in basis points over LIBOR or LIBOR equivalent for each dollar drawn down. Non-PC Bank is a dummy that equals 1 if the lead bank does not have political connections, and zero otherwise. All variables are defined in Table 1.

\begin{tabular}{|c|c|c|}
\hline & \multicolumn{2}{|c|}{ Ln (Spread) } \\
\hline & $(1)$ & $(2)$ \\
\hline $\mathrm{TPC}_{\mathrm{t}}$ & $\begin{array}{c}-3.719 * * * \\
(-3.861)\end{array}$ & \\
\hline Non-PC Bank $k_{t}$ & $\begin{array}{c}-1.177 \\
(-1.470)\end{array}$ & \\
\hline $\mathrm{TPC}_{\mathrm{t}} \times$ Non-PC Bank $\mathrm{t}_{\mathrm{t}}$ & $\begin{array}{c}2.501 * * \\
(2.281)\end{array}$ & \\
\hline $\mathrm{RPC}_{\mathrm{t}}$ & & $\begin{array}{c}2.608 * * \\
(2.276)\end{array}$ \\
\hline Non-PC Bank ${ }_{t}$ & & $\begin{array}{c}0.649 \\
(0.916)\end{array}$ \\
\hline $\mathrm{RPC}_{\mathrm{t}} \times$ Non-PC Bank $\mathrm{t}_{\mathrm{t}}$ & & $\begin{array}{c}-2.196 \\
(-1.289) \\
\end{array}$ \\
\hline Constant & Yes & Yes \\
\hline Firm Characteristics & Yes & Yes \\
\hline Loan Characteristics & Yes & Yes \\
\hline Loan-Type FE & Yes & Yes \\
\hline Loan-Purpose FE & Yes & Yes \\
\hline Industry FE & Yes & Yes \\
\hline Year FE & Yes & Yes \\
\hline No. of Loan Facilities & 132 & 132 \\
\hline No. of Firms & 40 & 40 \\
\hline Adjusted $R^{2}$ & 0.422 & 0.428 \\
\hline
\end{tabular}


Table 9. Approaches to political connections, agency costs, and the cost of debt

This table presents the pooled ordinary least square regression results for the effect of agency costs on the relationship between types of political connections and the cost of debt. We use two measures of information asymmetry to proxy agency costs; positive accounting accrual (ACCR) and stock return volatility (SDRET). All other variables are defined in Table 1 . The $t$-statistics, reported in parentheses, are based on standard errors clustered at the firm level.

\begin{tabular}{lcccc}
\hline & \multicolumn{2}{c}{ ACCR } & \multicolumn{2}{c}{ SDRET } \\
\cline { 2 - 5 } & $-0.016^{* *}$ & & $-0.029^{* * *}$ & $(4)$ \\
\hline TPC $_{(\mathrm{t}-1)}$ & $(-2.416)$ & & $(-2.800)$ & \\
AGENCYCOSTS $_{(\mathrm{t}-\mathrm{l})}$ & 0.002 & 0.001 & $-0.011^{*}$ & -0.007 \\
& $(1.091)$ & $(0.477)$ & $(-1.719)$ & $(-1.169)$ \\
TPC $_{(\mathrm{t}-1)} \times$ AGENCYCOSTS $_{(\mathrm{t}-1)}$ & $-0.016^{*}$ & & $-0.011^{*}$ & \\
& $(-1.658)$ & & $(-1.719)$ & \\
RPC $_{(\mathrm{t}-1)}$ & & 0.029 & & 0.017 \\
& & $(1.502)$ & & $(0.509)$ \\
RPC $_{(\mathrm{t}-1)} \times$ AGENCYCOSTS $_{(\mathrm{t}-1)}$ & & -0.020 & & 0.027 \\
& & $(-0.567)$ & & $(0.315)$ \\
Constant & & & & \\
& $0.050^{* * *}$ & $0.053^{* * *}$ & $0.061^{* * *}$ & $0.064^{* * *}$ \\
& $(3.960)$ & $(4.085)$ & $(4.595)$ & $(4.719)$ \\
\hline Firm Characteristics & Yes & Yes & Yes & Yes \\
Industry FE & Yes & Yes & Yes & Yes \\
Year FE & Yes & Yes & Yes & Yes \\
Observations & 1997 & 1997 & 1772 & 1772 \\
Adjusted $R^{2}$ & 0.215 & 0.204 & 0.221 & 0.213 \\
\hline
\end{tabular}

